\title{
Determinant Factors of Bank Financial Reporting Quality; Study at Regional Development Banks in Sumatra
}

\author{
Susfa Yetti Nela Safelia Afrizal* \\ Faculty of Economics and Business of Jambi University, Jambi, Indonesia
}

\begin{abstract}
This study examined the simultaneous influence of performance credibility, go-public companies, company director with adequate auditing experience, age of $\mathrm{CEO}$, material weakness disclosure, changes in public accountant, connection between CEO with the government, and Good Corporate Governance on the quality of financial reporting of Regional Development Banks in Sumatera. This study also analyzed the partial influences of Independent variables on the quality of financial statements of Regional Development Banks in Sumatera, and determined the variable with the strongest influence on the quality of financial statements of regional banks in Sumatera. Secondary data were analyzed using logistic regression tests. Sample in this study is all of Regional Development Banks in Sumatera. The hypotheses of this study consist of three types of tests; Simultaneous Significance Test (F test), Individual Parameter Significance Test (T-test), and Coefficient Determination Test (R2). The results of the data analysis showed that : the first, performance credibility, go-public companies, company director with adequate auditing experience, age of CEO, changes in public accountant, connection between CEO with the government, ,material weakness disclosures, and Good Corporate Governance simultaneously affected the quality of financial statements reporting at regional banks in Sumatera. Secondly, material weakness disclosures and Good Corporate Governance had partial influence on the quality of the financial reporting, Meanwhile, performance credibility, go-public companies, directors with auditing experience, age of $\mathrm{CEO}$, changes in public accountant, and the connection between $\mathrm{CEO}$ with the government had not partial influence on the quality of the financial reporting. Third, All variable was found influence significance $(65 \%)$ on the quality of financial reporting of regional banks in Sumatera.
\end{abstract}

Keywords: Good corporate governance, public accountant and quality of financial statements

DOI: $10.7176 /$ RJFA/11-17-19

Publication date:October $31^{\text {st }} 2020$

\section{INTRODUCTION}

\subsection{Research Background}

Accounting is a means of communication in the business world can helping to control and secure written property, and it is an essential tool helping to settle the financial affairs of a company and government. Accounting is a process of recording all financial transactions activities generating the finished product considered a financial report. In accounting science, a financial report will consist of 5 core components, namely: (1) Balance Sheet, (2) Profit and Loss Statement, (3) Cash Flow Statement, (4) Change Statement of Profit or Change in Equity, and Notes to Financial Statements.

Financial Reporting can be defined as a process to prepare financial reports, starting from identification, recording, calculating to producing those financial statements. With the existence of financial reporting, it can describe information regarding how the company performance is; how the asset position is; how the liabilities and capital of the company are. In addition, the reporting can also describe how in and out of cash flows from a company activity. This information is critical for financial report users as a reference for them in making decisions. Therefore, the quality of financial reporting is very much required for its users, like investors, creditors, company owners, banks and the government.

In the accounting conceptual framework, it is stated that the process of financial reporting includes identification and analysis of corporate events and transactions, application of accounting policies, selection of accounting policies, maintaining professional accounting estimates as well as judgments and disclosures.

Regional Development Banks (Bank Pembangunan Daerah; BPD) is a bank owned by local governments, such as provincial, regency and city governments, in which its capital consists of the shares they invest in the BPD. The BPD's activity is to collect public funds like savings and channel them back to the community in the form of credit and other forms. In addition, BPD has a function and role as a government partner in the context of regional economic development. It is because BPD is able to extend branches in serving the community to all corners of the region. BPD is called a government partner in advancing regional development and regional economic development.

In Indonesia, there are 26 BPDs in every province, and 8 BPDs spread across Sumatra. In Sumatra, BPDs are very frequently and widely used by the government for their political interests.

From the research background, the writer is interested in examining how the determinant factors affect the financial reporting quality submitted by Regional Development Banks (Bank Pembangunan Daerah; BPD) spread 
across Sumatra.

\subsection{Research Question}

Starting from the aforementioned research background, several question problems can be formulated as follows:

(1) Do the independent variables collectively possess a significant effect on the financial reporting quality at Regional Development Banks spread across Sumatra?

(2) How do the independent variables partially affect the financial reporting quality at Regional Development Banks spread across Sumatra?

(3) BHow much effect does independent variables have on financial reporting quality at Regional Development Banks spread across Sumatra?

\subsection{Research Objective}

This study aims at obtaining empirical evidence and discovering clarity regarding the factors affecting the financial reporting quality presented by the Regional Development Bank spread across Sumatra, and for more details as follows:

To analyze whether the independent variables collectively or partially have a significant effect on the financial reporting quality at Regional Development Banks spread across Sumatra, and how much effect of independent variables on the financial reporting quality at Regional Development Banks spread across Sumatra.

\subsection{Benefit and Target of Research}

\subsubsection{Benefit of Research}

The study results are expected to provide 2 (two) main uses, namely;

(1) Operational. It is hoped that it can be used as useful information for all financial report users of Regional Development Bank in Sumatra regarding the information quality contained in their financial reports.

(2) Science Development. It is hoped that it can contribute to the development of accounting science in Sumatra, especially regarding factors that can affect the financial reporting quality provided by the Regional Development Bank in Sumatra.

\section{Theoretical Framework}

\subsection{Agency Theory}

Agency theory is an implementation in modern organizations. This theory emphasizes the importance of company owners (shareholders) handing over the management of the company to qualified staff called agents understanding better in carrying out routine business (Mathius, 2016). Agency theory is a version of game theory designing a contractual model between two or more people (parties), in which one party is called an agent and the other is called a principal. Agency theory is the basis for disclosure made by management (agents) to business owners (Jensen and Meckling 1976).

Agency theory is a condition occurring in a company in which the management as the executor is further referred to as the agent and the owner of capital as the principal creates a cooperation contract (Fahmi, 2015).

\subsection{Signalling theory}

Signalling theory is a theory describing how a company should provide signals to users of financial reports. This signal is in the form of information regarding what management has done to realize the owner's wishes, which can be in the form of promotions or information stating that the company is better than other companies.

Companies having confidence regarding good prospects in the future will tend to communicate this news to investors. Therefore, companies with proper quality will provide signals by submitting company financial reports in a timely manner. Meantime, companies with insufficient quality will be late in submitting financial reports (Hanafi and Halim, 2016).

According to Jogiyanto (2014), information published as an announcement will provide signals for investors in making decisions for investment. When the information is announced, market players will first interpret and analyze the information as a proper signal (good news) or a terrible signal (bad news). If the announcement of this information is considered a proper signal, investors will be interested in trading stocks. One type of information released by a company is information related and unrelated to financial reports.

\subsection{Accounting}

The business world requires a tool that can be used as a device in communicating and interpreting an information system regarding the company's business activities. This tool is known as accounting. Accounting is recognized as an information system, in which all business activities can be measured. The data are processed into information, which is in the form of reports, and then the output is communicated to decision makers or stakeholders.

Stakeholders using financial reports can be grouped as follows: 
1. Management and company employees

2. Investors

3. Creditors

4. Company owner

5. Tax Officer or government

6. Financial analyst

7. Supplier

A proper financial report is a report that can provide benefits to users, therefore financial report must possess exceptional quality, ad if it can be clearly to be understood; it has consistency; it has comparable potency; it is relevant; it can be compared to other; and it can be evaluated.

\subsection{Financial Report}

The financial report is the final product of an accounting implementation process. The financial report has 5 (five) report components, each of which is an integral part of a comprehensive financial report. The components of these financial reports are balance sheets, profit and loss calculations, cash flow statements, changes in financial position or changes in retained earnings, and notes to financial reports. The balance sheet is a description of the company's financial position at a certain time or date, usually as of December 31. Profit and loss calculations provide information regarding the company's income, cost, and financial performance for a certain period, usually a period of one year from January 1 to December 31 of the same year. The cash flow statement describes all the sources of incoming money and what they were expended on during a given period. Changes in financial position describe changes in equity and changes in the company's profit and loss over a certain period. Notes to financial reports are an additional explanation, so that the financial reports can be interpreted correctly.

According to Hutauruk (2017), the purpose of financial reports is to provide information regarding the financial position, performance and changes in the financial position of an entity useful for numerous users in making economic decisions. Financial reports are presented to stakeholders to assist them in making social, political and economic decisions, so that decisions can be performed in more exceptional quality (Mardiasmo 2018).

\subsection{Previous Research}

Based on the results of previous studies abroad, it was found that many identified variables affect the quality of financial reporting. These variables are as follows:

Performance credibility (liang, Marinovic, and Varas : 2018), Go public company (Hops, Thomas, and Vyas : 2013)., Explanation of the auditor's findings (Nagar and Petach: 2016)., The experience of director as an auditor (Krishnan, Wen, and Zhao : 2011 ). The age of CEO (huang, green, and Lee,(2012), disclosure of material weaknesses (Emma and Myllymaki : 2013), change in audit partner (Litt, Simsons, and Tanyl: 2014), quality of audit (Gaynor, kelton, Mercer, Yohn : 2016), connection between CEO and government (Avishek Bhandari , Babak mammadov, Austin Shelton, and maya Thevenot: 2018), internal control (Asare, Fitzgerald, Graham, Joe, Nagangard, and Wolfe: 2013), Financial reporting Quality of U.S Private and public Firm. ( 2013), family owned company (Bardhan, Lin, and $\mathrm{Wu}: 2015$ ),

\subsection{Financial reporting quality}

In research, the quality of a financial report having a certain quality is a report that the results of the external party audit get an unqulified opinion (Wajar Tanpa Pengecualian; WTP). Meanwhile, unqulified companies are companies receiving an opinion from an external audit party other than the unqualified opinion (Wajar Tanpa Pengecualian; WTP).

\subsection{Variables Affecting the Financial Reporting Quality}

Based on the aforementioned the previous studies results, it was found that many identified variables affect the quality of financial reporting. However, based on the condition of the Regional Bank in Sumatra, the following variables will be examined:

1. Performance credibility

2. Go public company

3. The experience of director as an auditor

4. The age of CEO

5. Disclosure of material weaknesses

6. Change in public accountants

7. Connection between CEO and government

8. Good Corporate Governance 


\subsection{Hypothesis}

Starting from the problem, the theoretical framework can be reduced to the hypothesis as follows

First Hypothesis

The independent variables collectively have a significant effect on the quality of financial reporting at Regional Development Banks spread across Sumatra.

\section{Second Hypothesis}

The independent variables collectively have a significant effect on the quality of financial reporting at Regional Development Banks spread across Sumatra

\section{Third Hypothesis}

The independent variable has an adequate significant effect on the quality of financial reporting at Regional Development Banks spread across Sumatra.

\subsection{Strategic Plan and Time line of Research}

The research time line can be seen in Figure 1 below:

Figure 2.2:

Research time line

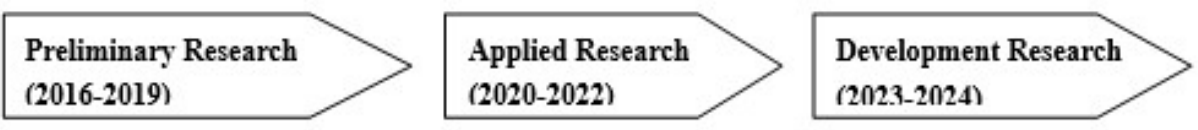

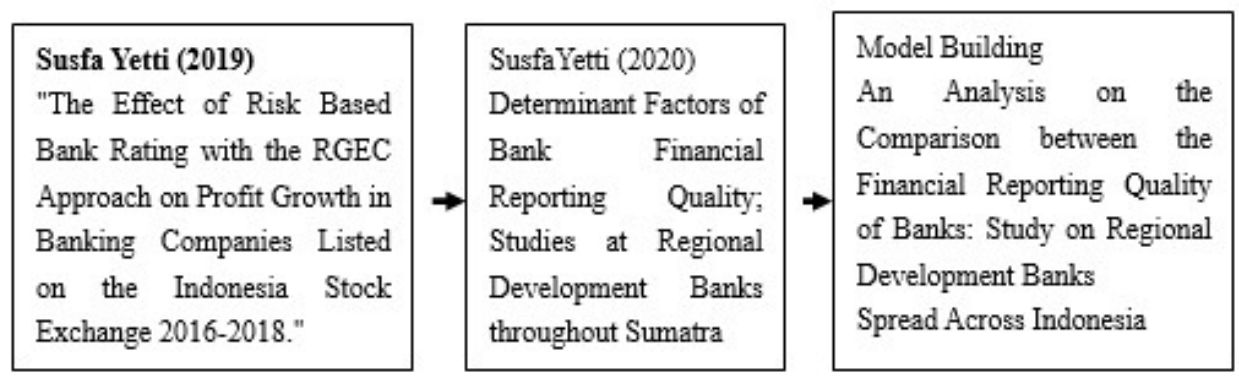

Universitas Jambi (UNJA) has formulated a strategic plan for research in the Research Master Plan (Rencana Induk Penelitian; RIP) 2016-2020. The increase in the performance of the Research Institutions and Community Service of Universitas Jambi can be measured by the number of research titles in accordance with the RIP UNJA. Researchers at UNJA must refer to the RIP. This research is part of the RIP to achieve the main objectives of the RIP UNJA. Therefore, researchers will conduct research in line with the research topics contained in the RIP UNJA 2016-2020, namely the fields of economics and finance with the theme of financial institutions and products.

\section{RESEARCH METHODS}

\subsection{Research object}

The research object is the Regional Development Banks in Sumatra. The number of Regional Development Banks registered with the OJK is 8 banks, and the banks' names can be seen in the Appendix.

\subsection{Research Method}

In this study, the research method employed was a survey method, collecting data (information) from regional development banks included in the research object. Meanwhile, the data used were primary and secondary data, that is, either directly taken from the research object company or data from the OJK, Bank Indonesia, and other relevant institutions.

\subsection{Population and Sample}

The number of company populations becoming the research object are 8 active Regional Development Banks in Sumatra from 2016 to 2019 . The sampling method employed is saturated samples, so all existing population will be taken as the sample.

\subsection{Variable Operationalization (Y).}

Each of the research variables will be operationalized as follows:

(1) Dependent variable (Y)

In this study, it was consisted of 1 (one) dependent variable, namely the variable of financial reporting quality which 
is a dummy variable of 2 categories with a nominal scale.

-Financial reports quality: the indicator is if the results of the audit opinion are Unqualified opinion (or Wajar Tanpa Pengecualian; WTP), it is given a score of 1

-The financial reports are unqualified: If the audit opinion is the unqualified opinion (or Unqualified, Unreasonable, and refuses to give an opinion), it will be rated 0

(2) Independent Variable $\left(\mathrm{X}_{1}-\mathrm{X}_{10}\right)$.

In this study, the independent variables are as follows:

$\mathrm{X}_{1}=$ Performance credibility

$\mathrm{X}_{2}=$ Go public company

$\mathrm{X}_{3}=$ The experience of director as an auditor

$\mathrm{X}_{4}=$ The age of CEO

$\mathrm{X}_{5}=$ Disclosure of material weaknesses

$\mathrm{X}_{6}=$ Change in public accountants

$\mathrm{X}_{7}=$ Connection between $\mathrm{CEO}$ and government

$\mathrm{X}_{8}=$ Good Corporate Governance

\subsection{Data Collection Technique}

The data collection technique for each variable was carried out using a list of questions (questionnaire) with the following details:

a. Primary data for the dependent and the independent variable were taken through a list of questions to the Regional Development Bank submitted through the company leadership (director).

b. Secondary data were taken from the annual reports of each regional development bank in Sumatra through the local OJK or financial reports for 2016, 2017, 2018, and 2019 having been audited and officially reported to the local OJK.

\subsection{Data analysis Method}

This research uses quantitative analysis method both descriptively and inferentially. Descriptive analysis is performed by preparing direct tabulations of the data from the variables to be analyzed, then comparing the percentage values and their averages. Furthermore, inferential analysis to see the effect of independent variables on financial reporting quality (Y) is used multiple logistic regression analyses because of its compatibility with the dichotomous scale of the dependent variable measurement or two categories of nominal scale. The choice of multiple logistic regressions or logit model is considered suitable because the dependent variable of this study is a nominal scale or dichotomous, and many of the independent variables have nominal and interval scales.

Hence, for this study, the regression model can be formulated as follows:

(1) To determine the effect of the independent variables collectively on the quality of financial reporting (Y), the model is as follows:

a. The logistics transformation:

$\operatorname{Logit} \mathrm{P}(\mathrm{Y}))=\beta_{\mathrm{o}}+\beta_{1} \mathrm{X}_{1} \ldots+\beta_{8-} \mathrm{X}_{8}+\varepsilon_{\mathrm{i}}$

b. The logistic regression model:

$$
P\left(Y_{1 i}\right)=1 /\left\{1+\exp \left[-\left(\beta_{0}+\beta_{1} X_{1} \ldots+\beta_{10} X_{10}\right)\right]\right\}
$$

(2) To determine the effect of the independent variable (individually) on the quality of financial reporting (Y), the model is as follows:

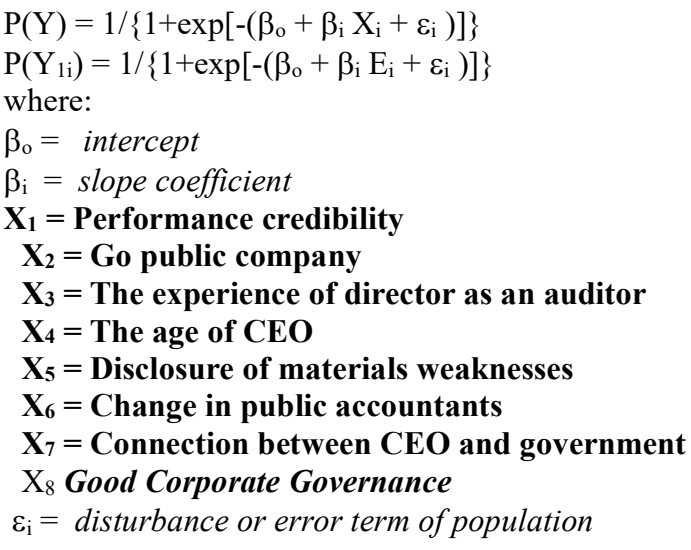

\subsection{Hypothesis Testing Design}

The stages of testing with Multiple Logistic Regression are as follows: 
(1) Calculating the estimated Multiple Logistic Regression equation as follows:

$\mathrm{P}\left(\mathrm{Y}_{1 \mathrm{i}}\right)=1 /\left\{1+\exp \left[-\left(\beta_{\mathrm{o}}+\beta_{1} \mathrm{X}_{1} \ldots+\beta_{10} \mathrm{X}_{10}\right)\right]\right\}$

(2) Calculating the $G$ value to get the $p$-value, with the following formula:

$\mathrm{G}=-2\left[\left(\right.\right.$ Likelihood $_{2}-$ Likelihood $\left.\left._{1}\right)\right]$

where:

Likelihood $_{1}=$ likelihood including constants

Likelihood $_{2}=$ likelihood unincluding constants

(Hosmer and Lemeshow, 1989)

(3) Determining Confidence Interval or value $\alpha$ (in this study used $\alpha=0,05$ ).

(4) Calculating the p-value using the $G$ value.

(5) Performing significance testing by comparing the p-value with $\alpha=0,05$. If the p-value is smaller than the level $\alpha=$ 0,05 , the null hypothesis is rejected. Otherwise, if the $\mathrm{p}$-value is greater than the level $\alpha=0,05$, the null hypothesis is accepted (Hosmer and Lemeshow, 1989).

(6) Determining the variables having a significant effect by using the Wald Test. If the Wald Test value exceeds 2 (two), these variables are significant. Otherwise, if the Wald Test value is below 2, the variable is not significant. The Wald Test is calculated using the following formula:

$\mathrm{WT}=\beta / \mathrm{S}_{\beta}$

$\beta=$ logistic regression coefficient estimate

$\mathrm{S}_{\beta}=$ standard error

(7) Calculating the individual and collective probability of the independent variables on the dependent variable using the logistic model formula as follows:

$\mathrm{Pi}=\mathrm{E}_{\mathrm{s}}\left(\mathrm{Y}=1 / \mathrm{X}_{\mathrm{i}}\right)=1 /\left(1+\mathrm{e}^{-\mathrm{Zi}}\right)$ dan $\mathrm{Pi}=\mathrm{E}_{\mathrm{s}}\left(\mathrm{Y}=1 / \mathrm{E}_{\mathrm{i}}\right)=1 /\left(1+\mathrm{e}^{-\mathrm{Zi}}\right)$ where, $Z_{i}=\beta_{1}+\beta_{2} X_{i}$ (Gujarati, 1988).

(8) The next conclusion is almost the same as Multiple Regression Analysis. However, the final result of this analysis is in the form of an estimated probability and not in the form of an exact probability (Kleinbaum, 1994).

\subsection{Research Flow Chart}

Based on the aforementioned research background and preliminary analysis, a flow chart of this research can be drawn up as shown in the figure below:

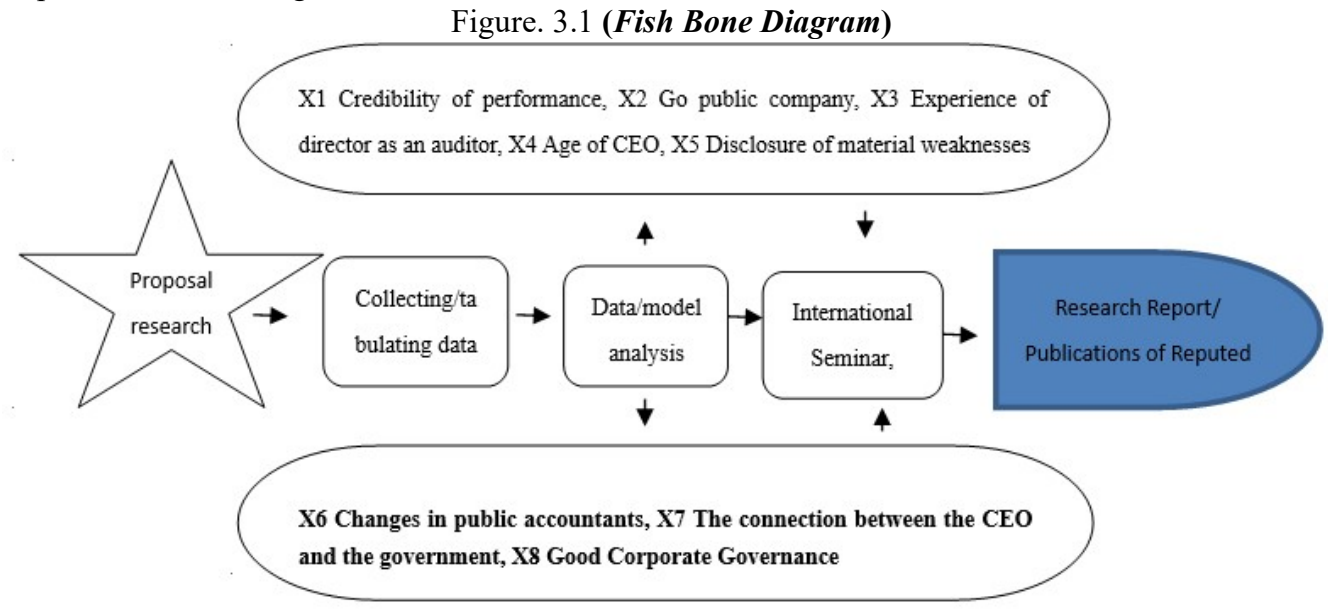

\section{DATA ANALYSIS AND DISCUSSION}

\subsection{Descriptive statistics}

The following will explain descriptive statistics, namely explaining data descriptions of all variables to be included in the research model. In this study, the dependent variable was the quality of financial reporting, while the independent variables were performance credibility, go public companies, the experience of the director as an auditor, the age of the CEO, disclosure of material weaknesses, changes/rotation of accountants, the connection between CEO and the government, GCG. More details information can be seen in the following table 4.2: 
Table 4.2

Descriptive Statistics

\begin{tabular}{|l|c|c|c|c|c|}
\hline & $\mathrm{N}$ & Minimum & Maximum & Mean & Std. Deviation \\
\hline Financial reporting quality & 32 & 0 & 1 & .56 & .504 \\
x1 & 32 & 0 & 1 & .81 & .397 \\
x2 & 32 & 0 & 1 & .22 & .420 \\
x3 4 X & 32 & 0 & 1 & .22 & .420 \\
x5 & 32 & 50 & 58 & 54.22 & 2.012 \\
x6 & 32 & 0 & 5 & 1.22 & 1.581 \\
x7 & 32 & 0 & 1 & .75 & .440 \\
x8 & 32 & 0 & 1 & .19 & .397 \\
Valid N (listwise) & 32 & 2 & 3 & 2.41 & .499 \\
\hline
\end{tabular}

Source: Results of Processed Data by SPSS, 2020

Descriptive analysis results of the dependent variable, financial reporting quality, of 32 samples tested showed that the value of financial reporting quality in the sample had a minimum value of 0 and a maximum value of 1 . With an average value of 0.56 or $56 \%$, the standard deviation was 0.504 .

Descriptive analysis results of the independent variable, performance credibility, of 32 samples tested showed that the value of performance credibility in the sample had a minimum value of 0 and a maximum value of 1 . It means that with an average value of 0.81 or $81 \%$, a standard deviation of performance credibility of the average company was 0.397 .

Descriptive analysis results of go public company variables of 32 samples tested showed that go public company variable has a minimum value of 0 and a maximum value of 1 . Meanwhile, the average value of the go public company variable is 0.22 or $22 \%$, and the standard deviation is 0.420 .

Descriptive analysis results of the independent variable, the director as an auditor, of 32 samples tested showed that the director as an auditor variable has a minimum value of 0 and a maximum value of 1 . Meanwhile, the average value of the director as an auditor variable is 0.22 or $22 \%$, and the standard deviation is 0.420 .

Descriptive analysis results of the independent variable, the age of CEO, of 32 samples tested showed that the age of the CEO variable has a minimum value of 50 and a maximum value of 58 , while the average value of it is 54.22 or $5.422 \%$, and a standard deviation is 2.012

Descriptive analysis results of the independent variable, fraud findings, of 32 samples tested was obtained an average of 1.22 or $122 \%$ with minimum value of 0 and a maximum value of 1 . Standard deviation is 1,581 .

Descriptive analysis results of the independent variable, change in accountants, of 32 samples tested showed that change in accountants has a minimum value of 0 and a maximum value of 1 . Meanwhile, the average value of the change in accountants variable is 0.75 or $75 \%$, and the standard deviation is 0.440 .

Descriptive analysis results of the independent variable, connection between CEO and government, of 32 samples tested showed that the connection between CEO and government variable has a minimum value of 0 and a maximum value of 1 . Meanwhile, the average value of the connection between CEO and government variable is 0.19 or $19 \%$, and the standard deviation is 0.246 .

Descriptive analysis results of the independent variable, GCG, of 32 samples tested showed that GCG variable has a minimum value of 2 and a maximum value of 3 . Meanwhile, the average value of the GCG variable is 2.41 or $241 \%$, and the standard deviation is 0.499 .

\subsection{Logistic Regression Analysis}

\subsubsection{Testing Overall Model Fit}

This step is required to test whether the overall model fits with the data. It is applied by comparing -2Log Likelihood (-2LL) in the beginning block, where the model only has constants with -2Log Likelihood (-2LL), in block one, which is when the model has constants and independent variables. In testing the overall fit model, a 2LLL (-2LL) value in the initial block is 43.860, and a -2Log Likelihood (-2LL) value in block one is 22.416. The eight independent variables are entered into the model. It shows that the hypothesized model fits with the data. Besides, seeing the -2LL value, the Chi-square value on the omnibus test of model coefficient can also be a reference for testing the overall model. 
Table 4.3

Testing Result $-2 \log L$ ( Block number $=0)$

Iteration History ${ }^{\mathrm{a}, \mathrm{b}, \mathrm{c}}$

\begin{tabular}{|c|c|c|c|}
\hline \multirow[b]{2}{*}{ Iteration } & & \multirow[b]{2}{*}{-2 Log likelihood } & Coefficients \\
\hline & & & Constant \\
\hline \multirow[t]{3}{*}{ Step 0} & 1 & 43.860 & .250 \\
\hline & 2 & 43.860 & .251 \\
\hline & 3 & 43.860 & .251 \\
\hline
\end{tabular}

a. Constant is included in the model.

b. Initial -2 Log Likelihood: 43.860

c. Estimation terminated at iteration number 3 because parameter estimates changed by less than ,001.

Table 4.4

Testing Result $-2 \log L($ Block number $=1)$

Iteration History ${ }^{a, b, c, d}$

\begin{tabular}{|c|c|c|c|c|c|c|c|c|c|c|}
\hline \multirow[b]{2}{*}{ Iteration } & \multirow{2}{*}{$\begin{array}{c}-2 \log \\
\text { likelihood }\end{array}$} & \multicolumn{9}{|c|}{ Coefficients } \\
\hline & & Constant & $\mathrm{x} 1$ & $\mathrm{x} 2$ & $\mathrm{x} 3$ & $\mathrm{x} 4$ & $\mathrm{x} 5$ & $\mathrm{x} 6$ & $\mathrm{x} 7$ & $\mathrm{x} 8$ \\
\hline Step 11 & 27.052 & -35.579 & 3.524 & 3.588 & -.666 & .433 & -.779 & 1.231 & .724 & 3.630 \\
\hline 2 & 23.839 & -54.802 & 5.888 & 6.227 & -1.417 & .649 & -1.279 & 1.513 & 1.217 & 6.013 \\
\hline 3 & 22.710 & -71.209 & 8.303 & 8.991 & -2.302 & .819 & -1.749 & 1.604 & 1.605 & 8.294 \\
\hline 4 & 22.449 & -81.665 & 10.492 & 11.347 & -3.031 & .910 & -2.074 & 1.672 & 1.861 & 9.890 \\
\hline 5 & 22.420 & -85.797 & 12.022 & 12.902 & -3.347 & .935 & -2.191 & 1.692 & 1.950 & 10.484 \\
\hline 6 & 22.418 & -87.139 & 13.088 & 13.969 & -3.385 & .938 & -2.204 & 1.695 & 1.959 & 10.552 \\
\hline 7 & 22.417 & -88.144 & 14.089 & 14.971 & -3.386 & .938 & -2.204 & 1.695 & 1.959 & 10.552 \\
\hline 8 & 22.416 & -89.144 & 15.090 & 15.971 & -3.386 & .938 & -2.204 & 1.695 & 1.959 & 10.552 \\
\hline 9 & 22.416 & -90.144 & 16.090 & 16.971 & -3.386 & .938 & -2.204 & 1.695 & 1.959 & 10.552 \\
\hline 10 & 22.416 & -91.144 & 17.090 & 17.971 & -3.386 & .938 & -2.204 & 1.695 & 1.959 & 10.552 \\
\hline 11 & 22.416 & -92.144 & 18.090 & 18.971 & -3.386 & .938 & -2.204 & 1.695 & 1.959 & 10.552 \\
\hline 12 & 22.416 & -93.144 & 19.090 & 19.971 & -3.386 & .938 & -2.204 & 1.695 & 1.959 & 10.552 \\
\hline 13 & 22.416 & -94.144 & 20.090 & 20.971 & -3.386 & .938 & -2.204 & 1.695 & 1.959 & 10.552 \\
\hline 14 & 22.416 & -95.144 & 21.090 & 21.971 & -3.386 & .938 & -2.204 & 1.695 & 1.959 & 10.552 \\
\hline 15 & 22.416 & -96.144 & 22.090 & 22.971 & -3.386 & .938 & -2.204 & 1.695 & 1.959 & 10.552 \\
\hline 16 & 22.416 & -97.144 & 23.090 & 23.971 & -3.386 & .938 & -2.204 & 1.695 & 1.959 & 10.552 \\
\hline 17 & 22.416 & -98.144 & 24.090 & 24.971 & -3.386 & .938 & -2.204 & 1.695 & 1.959 & 10.552 \\
\hline 18 & 22.416 & -99.144 & 25.090 & 25.971 & -3.386 & .938 & -2.204 & 1.695 & 1.959 & 10.552 \\
\hline 19 & 22.416 & -100.144 & 26.090 & 26.971 & -3.386 & .938 & -2.204 & 1.695 & 1.959 & 10.552 \\
\hline 20 & 22.416 & -101.144 & 27.090 & 27.971 & -3.386 & .938 & -2.204 & 1.695 & 1.959 & 10.552 \\
\hline
\end{tabular}

a. Method: Enter

b. Constant is included in the model.

c. Initial -2 Log Likelihood: 43.860

d. Estimation terminated at iteration number 20 because maximum iterations has been reached. Final solution cannot be found.

Assessing the fit model can be seen from the value of $-2 \log \mathrm{L}$, which is without taking into account the independent variable (Block number $=0$ ), which is 43,860 after including eight variables, the performance credibility, the go public company, the experience of the director as an auditor, the age of the CEO, disclosure of material weaknesses, the changes/rotation of the accountant, the connection between CEO and government, GCG. Then the value of $-2 \log \mathrm{L}$ (Block number $=1$ ) dropped to 22.416 , or there was a decrease of 21.444 . It can be compared by observing the Chi-square table by comparing the probability and deg-freedom. It can be produced $21.444>13.09051$. It means that the addition of new independent variables in the form of performance credibility, the company going public, the experience of the performance credibility, the go public company, the experience of the director as an auditor, the age of the CEO, disclosure of material weaknesses, the changes/rotation of the accountant, the connection between CEO and government, GCG into the model does not improve the rejected $\mathrm{H} 0$ model, meaning that the dependent variable is affected by outside factors other than the independent variable.

4.2.2 Test of Goodness of Fit

The feasibility of the regression model aims at assessing the suitability of the model with the data, assessed using 
the Hosmer and Lemeshow's Goodness of Fit Test as measured by the chi-square value. The probability of significance obtained is then compared with the significance level $\alpha$ of $5 \%$. The hypothesis to assess the feasibility of the regression model is:

$\mathrm{H} 0$ : There is no difference between the model and the data

$\mathrm{Ha}:$ There is difference between the model and the data

Table 4.5

Feasibility Test of Hosmer and Lemeshow's Model

\begin{tabular}{|l|r|r|r|}
\hline Step & Chi-square & df & \multicolumn{1}{c|}{ Sig. } \\
\hline 1 & 4.916 & 8 & .767 \\
\hline
\end{tabular}

Source: Results of Processed Data, 2020.

Based on table 4.5, it can be seen that from the eligibility criteria of the model tested, Hosmer and Lemeshow's Goodness of fit test has a Chi-square value of 4.916 and a significance value of 0.767 . A significance value was greater than 0.05 causing the hypothesis $\mathrm{H} 0$ to be accepted. It means there is no difference between the logistic regression model estimation data and the observational data, so the model is feasible and appropriate to be used. It means that the model used in the study generally can be said to be appropriate and feasible.

4.2.3 Testing the Determination Coefficient (Nagelkerke R Square )

The determination coefficient (Nagelkerke R Square) is used to determine how much the contribution of the independent variable to the dependent variable. The determination coefficient in the logistic regression can be seen in the Nagelkerke R Square value as follows:

Table 4.6

The Value of Nagelkerke R Square

\begin{tabular}{|c|c|c|c|}
\hline Step & -2 Log likelihood & Cox \& Snell R Square & Nagelkerke R Square \\
\hline 1 & $22,416^{\mathrm{a}}$ & .488 & .655 \\
\hline
\end{tabular}

a. Estimation terminated at iteration number 20 because maximum iterations has been reached. Final solution cannot be found.

Based on the results of table 4.6, it shows that the Nagelkerke R Square value is 0.655 . The value of Nagelkerke R Square shows that $65.5 \%$ of the quality of financial reporting at BPD in Sumatra is influenced by independent variables, namely performance credibility, go public company, experience of directors as auditors, the age of CEO, disclosure of material weaknesses, change/rotation of the accountants, connections between CEO and government and GCG. While the remaining 34.5\% explained the variability of other variables outside the research model. This value indicates there is a relationship between the independent variable and the dependent variable.

Table 4.7

Omnibus Tests of Model Coefficients

\begin{tabular}{|ll|r|r|r|}
\hline & & Chi-square & \multicolumn{1}{c|}{ df } & \multicolumn{1}{c|}{ Sig. } \\
\hline Step 1 & Step & 21.444 & 8 & .006 \\
& Block & 21.444 & 8 & .006 \\
& Model & 21.444 & 8 & .006 \\
\hline
\end{tabular}

Source: Results of Processed Data by SPSS, 2020

From the simultaneous test results (Omnibus Tests of Model Coefficients), it can be seen that the Chi-square value is 21.444 with a probability of 0.006 . Because the probability is smaller than 0.05 , the regression model can be used to predict that the probability is proxied by the performance credibility variable, the go public company, the experience of the director as an auditor, the age of the CEO, disclosure of material weaknesses, changes in public accountants, the connection between CEO and the government, GCG collectively has a significant effect on the quality of financial reporting.

4.2.4 HypothesisTesting

Hypothesis testing in logistic regression analysis uses the Wald test. This test is used to determine whether there is a significant effect of each independent variable on the dependent variable. Processing and calculating data used the program of SPSS 21 for Windows Operating System.

The logistic regression results will indicate the Wald value explaining the effect of the independent variable on the dependent variable. Hypothesis testing is carried out by comparing the probability (p) with the significance level $\alpha$. In testing this hypothesis, the probability value will be seen. If the p-value $<\alpha(5 \%)$, the hypothesis (Ha) is accepted, meaning that the independent variable partially has a significant effect on the dependent variable. If the $\mathrm{p}$-value $>\alpha(5 \%)$, hypothesis $(\mathrm{Ha})$ is rejected, meaning that the independent variable does not have a significant effect on the dependent variable. 
Table 4.9

Wald Test Results

Variables in the Equation

\begin{tabular}{|c|r|r|r|r|r|r|r|r|}
\hline & & & & & & & \multicolumn{2}{|c|}{$95 \%$ C.I.for EXP(B) } \\
\cline { 5 - 8 } & \multicolumn{1}{|c|}{ B } & \multicolumn{1}{|c|}{ S.E. } & Wald & df & Sig. & Exp(B) & Lower & Upper \\
\hline Step 1 $^{\mathrm{a}}$ x1 & 27.090 & 40192.950 & .000 & 1 & .999 & 582065633474.342 & .000 & .000 \\
x2 & 27.971 & 40192.950 & .000 & 1 & .999 & 1405229660154.924 & .000 \\
x3 & -3.386 & 3.126 & 1.173 & 1 & .279 & .034 & .000 & 15.489 \\
x4 & .938 & .484 & 3.751 & 1 & .053 & 2.555 & .989 & 6.601 \\
x5 & -2.204 & 1.078 & 4.181 & 1 & .041 & .110 & .013 & .913 \\
x6 & 1.695 & 1.498 & 1.279 & 1 & .258 & 5.445 & .289 & 102.658 \\
x7 & 1.959 & 1.639 & 1.429 & 1 & .232 & 7.093 & .286 & 176.129 \\
x8 & 10.552 & 5.133 & 4.227 & 1 & .040 & 38270.036 & 1.636 & 895274934.034 \\
Constant & -101.144 & 40192.966 & .000 & 1 & .998 & .000 & & \\
\hline
\end{tabular}

a. Variable(s) entered on step 1: x1, x2, x3, x4, x5, x6, x7, x8.

Source: Results of Processed Data by SPSS, 2020

Based on the results of processing table 4.9, the coefficient numbers are obtained, in which if transformed into logistic regression, it will take the following form:

$\mathrm{Y}=\beta 0-\beta 1 \mathrm{X} 1+\beta 2 \mathrm{X} 2+\beta 3 \mathrm{X} 3+\beta 4 \mathrm{X} 4+\beta 5 \mathrm{X} 5-\beta 6 \mathrm{X} 6-\beta 7 \mathrm{X} 7+\beta 8 \mathrm{X} 8+\varepsilon$

Thus, the results of the logistic regression equation are as follows:

$Y=-101,144+27,090 X 1+27,971 X 2-3,386 X 3+0,938 X 4-2,204 X 5+1,695 X 6+1,959 X 7+10,552 X 8+\varepsilon$

Y: Financial reporting quality

$\beta 0$ : Constanta

$\beta 1, \beta 2, \beta 3, \beta 4 \quad$ : regression coefficient

$\mathrm{X} 1$ : Performance credibility

X2 : Go public company

$\mathrm{X} 3$ : The Experience of Director as an Auditor

X4 : The age of CEO

$\mathrm{X} 5$ : Fraud Finding

X6 : Public accounting change/rotation

X7: Connection between $\mathrm{CEO}$ and government

$\mathrm{X} 8$ :GCG

$\varepsilon \quad:$ Error

that:

Based on the logistic regression equation model above, it can be seen

1. The constant coefficient of the regression results is $-101,144$ with a negative value,

meaning that the status of the financial reporting quality will be worth $-101,144$. Performance credibility, the go public company, the experience of the director as an auditor, the age of the CEO, the findings of fraud, changes/rotation of the accountants, the connection between CEO and government, GCG is equal to zero.

2. The coefficient of 27.090 means that for every increase in the performance credibility variable by $1 \%$, the status of financial reporting quality will increase by $2.709 \%$ with the assumption the value of go public company, the experience of the director as an auditor, the age of the CEO, the findings of fraud, changes/rotation of the accountants, the connection between CEO and government, GCG unchanged.

3 . The coefficient of 27.971 means that for every increase in the go public company variable by $1 \%$, the status of financial reporting quality will increase by $2.797 .1 \%$ with the assumption the value of performance credibility, the experience of the director as an auditor, the age of the CEO, the findings of fraud, changes/rotation of the accountants, the connection between CEO and government, GCG unchanged.

4. The coefficient of -3.386 means that for every increase in the experience of the director as an auditor variable by $1 \%$, the status of financial reporting quality will increase by $338.6 \%$ with the assumption the value of the performance credibility, go public company, the age of the CEO, the findings of fraud, changes/rotation of the accountants, the connection between CEO and government, GCG unchanged.

5. The coefficient of 0.938 means that for every increase in the age of the CEO variable by $1 \%$, the status of financial reporting quality will increase by $93.8 \%$ with the assumption the value of the performance credibility, go public company, the experience of the director as an auditor, the findings of fraud, changes/rotation of the accountants, the connection between CEO and government, GCG unchanged.

6. The coefficient of -2.204 means that for every increase in the findings of fraud variable by $1 \%$, the status of 
financial reporting quality will increase by $220.4 \%$ with the assumption the value of the performance credibility, go public company, the experience of the director as an auditor, the age of the CEO, changes/rotation of the accountants, the connection between CEO and government, GCG unchanged.

7. The coefficient of 1.695 means that for every increase in the changes/rotation of the accountants variable by $1 \%$, the status of financial reporting quality will increase by $169.5 \%$ with the assumption the value of performance credibility, go public company, the experience of the director as an auditor, the age of the CEO, the findings of fraud, the connection between CEO and government, GCG unchanged.

8 . The coefficient of 1,959 means that for every increase in the connection between CEO and government variable by $1 \%$, the status of financial reporting quality will increase by $195.9 \%$ with the assumption the value of the performance credibility, go public company, the experience of the director as an auditor, the age of the CEO, the findings of fraud, changes/rotation of the accountants, GCG unchanged.

9. The coefficient of 10.552 means that for every increase in the GCG variable by $1 \%$, the status of financial reporting quality will increase by $1055.2 \%$ with the assumption the value of the performance credibility, go public company, the experience of the director as an auditor, the age of the CEO, the findings of fraud, changes/rotation of the accountants, the connection between CEO and government unchanged.

4.2.5 Wald Testing

1. The effect of performance credibility on the quality of financial reporting.

The results of the regression calculation on the credibility of the performance obtained a Wald value of 0,000 and a probability of 0.999 . Thus, the probability calculation is greater than the significance value of 0.05 $(0.999>0.05)$, Ho is accepted, and $\mathrm{Ha}$ is rejected, meaning that the credibility of the performance partially does not have a significant effect on the quality of financial reporting.

2. The effect of go public company on the quality of financial reporting.

The results of the regression calculation in the go public company obtained a Wald value of 0,000 and a probability of 0.999 . Thus, the calculation of the probability is greater than the significance value of $0.05(0.999>$ 0.05), Ho is accepted, and Ha is rejected, meaning that the go public company partially has no significant effect on the quality of financial reporting

3. The effect of the experience of director as an auditor on the quality of financial reporting.

The results of the regression calculation in the experience of director as an auditor obtained a Wald value of 1,173 and a probability of 0.279 . Thus, the probability calculation is greater than the significance value of 0.05 $(0.279>0.05)$, Ho is accepted, and Ha is rejected, meaning that the experience of director as an auditor partially does not have a significant effect on the quality of financial reporting.

4. The effect of the age of the CEO on the quality of financial reporting.

The results of the regression calculation on the age of the CEO obtained a Wald value of 3,751 and a probability of 0.053 . Thus, the probability calculation is greater than the significance value of $0.05(0.053>0.05)$, Ho is accepted, and Ha is rejected, meaning that the the age of the CEO partially does not have a significant effect on the quality of financial reporting.

5. The effect of the finding of fraud on the quality of financial reporting.

The results of the regression calculation on the finding of fraud obtained a Wald value of 4,181 and a probability of 0.041 . Thus, the probability calculation is greater than the significance value of $0.05(0.041>0.05)$, Ho is rejected, and $\mathrm{Ha}$ is accepted, meaning that the the finding of fraud partially has a significant effect on the quality of financial reporting.

6. The effect of the change/rotation of the public accountants on the quality of financial reporting.

The results of the regression calculation in the change/rotation of the public accountants obtained a Wald value of 1,279 and a probability of 0.258 . Thus, the calculation of the probability is greater than the significance value of $0.05(0.258>0.05)$, Ho is accepted, and Ha is rejected, meaning that the change/rotation of the public accountants partially does not have no significant effect on the quality of financial reporting

7. The effect of the connection between CEO and the Government on the quality of financial reporting.

The results of the regression calculation in the connection between CEO and the Government obtained a Wald value of 1,429 and a probability of 0.232 . Thus, the probability calculation is greater than the significane value of $0.05(0.232>0.05)$, Ho is accepted, and Ha is rejected, meaning that the connection between CEO and the Government partially does not have a significant effect on the quality of financial reporting.

8. The effect of the GCG on the quality of financial reporting.

The results of the regression calculation on the of the GCG obtained a Wald value of 4,227 and a probability of 0.040 . Thus, the probability calculation is greater than the significance value of $0.05(0.040>0.05)$, Ho is rejected, and $\mathrm{Ha}$ is accepted, meaning that the the finding of fraud partially has a significant effect on the quality of financial reporting.

Recapitulation of Hypothesis Test Results can be seen in following table 4: 
Table 4.

Recapitulation of Hypothesis Test Results

\begin{tabular}{|c|c|c|c|c|}
\hline Hypothesis & Description & B & Sig. & Information \\
\hline 1 & $\begin{array}{l}\text { Performance credibility has a positive effect on the quality of financial } \\
\text { reporting. }\end{array}$ & 27.090 & 0.999 & $\begin{array}{c}\text { Not } \\
\text { supported }\end{array}$ \\
\hline 2 & Go public company has a positive effect on the quality of financial reporting. & 27.971 & 0.999 & $\begin{array}{c}\text { Not } \\
\text { supported }\end{array}$ \\
\hline 3 & $\begin{array}{l}\text { The experience of director as an auditor has a positive effect on the quality } \\
\text { of financial reporting. }\end{array}$ & -3.386 & 0.279 & $\begin{array}{c}\text { Not } \\
\text { supported }\end{array}$ \\
\hline 4 & The age of the CEO has a positive effect on the quality of financial reporting. & 0.938 & 0.053 & $\begin{array}{c}\text { Not } \\
\text { supported }\end{array}$ \\
\hline 5 & $\begin{array}{l}\text { The finding of fraud has a positive effect on the quality of financial } \\
\text { reporting. }\end{array}$ & -2.204 & 0.041 & Supported \\
\hline 6 & $\begin{array}{l}\text { The chance/rotation of the public accountants has a positive effect on the } \\
\text { quality of financial reporting. }\end{array}$ & 1.695 & 0.258 & $\begin{array}{c}\text { Not } \\
\text { supported }\end{array}$ \\
\hline 7 & $\begin{array}{l}\text { Connection between CEO and government has a positive effect on the } \\
\text { quality of financial reporting. }\end{array}$ & 1.959 & 1.639 & $\begin{array}{c}\text { Not } \\
\text { supported }\end{array}$ \\
\hline 8 & The GCG has a positive effect on the quality of financial reporting. & 10.552 & 0.040 & Supported \\
\hline
\end{tabular}

\subsection{Discussion of Research Results}

A. The effect of performance credibility on the quality of financial reporting.

The results of the regression calculation on the credibility of the performance obtained a Wald value of 0,000 and a probability of 0.999 . Thus, the probability calculation is greater than the significance value of $0.05(0.999>0.05)$, Ho is accepted, and $\mathrm{Ha}$ is rejected, meaning that the credibility of the performance partially does not have a significant effect on the quality of financial reporting.

B. The effect of go public company on the quality of financial reporting.

The results of the regression calculation in the go public company obtained a Wald value of 0,000 and a probability of 0.999 . Thus, the calculation of the probability is greater than the significance value of $0.05(0.999>0.05)$, Ho is accepted, and $\mathrm{Ha}$ is rejected, meaning that the go public company partially has no significant effect on the quality of financial reporting

This study is not in line with research conducted by Ole-Kristian Hope's (2013) stating that go public company has higher financial reporting quality and are more conservative, where go public company consistently reflect a higher demand for financial information because they can mitigate or eliminate profit management.

The effect of the experience of director/CEO as an auditor on the quality of financial reporting.

The results of the regression calculation in the experience of CEO as an auditor obtained a Wald value of 1,173 and a probability of 0.279 . Thus, the probability calculation is greater than the significance value of 0.05 $(0.279>0.05)$, Ho is accepted, and Ha is rejected, meaning that the experience of director as an auditor partially does not have a significant effect on the quality of financial reporting.

This study is not in line with research conducted by Galih (2013) showing that experience has a negative effect on the quality of financial reports, while according to Anugraheni (2013) experience has a positive effect on the quality of financial information presentation.

the more experience one has, especially in auditing and accounting, the more quality the financial statements will be.

D. The effect of the age of the CEO on the quality of financial reporting.

The results of the regression calculation on the age of the CEO obtained a Wald value of 3,751 and a probability of 0.053 . Thus, the probability calculation is greater than the significance value of $0.05(0.053>0.05)$, Ho is accepted, and Ha is rejected, meaning that the the age of the CEO partially does not have a significant effect on the quality of financial reporting.

This study is not in line with the research of Soslisa and Mukhlasin (2008) stating that the age of CEO has a significant effect on the tendency of accounting fraud. Based on this study, it can be said that the age of CEO has an effect on low quality of financial reports.

This study is in line with the research conducted by Hua-Wei-huang, Ena rose Green and Chih Chen Lee (2012) showing that there was a significant negative relationship between the age of CEO and the quality of financial reports.

E. The effect of the Disclosure of material weaknesses on the quality of financial reporting.

The results of the regression calculation on the finding of fraud obtained a Wald value of 4,181 and a probability of 0.041 . Thus, the probability calculation is greater than the significance value of $0.05(0.041>0.05)$, Ho is rejected, and $\mathrm{Ha}$ is accepted, meaning that the the finding of fraud partially has a significant effect on the quality 
of financial reporting.

This study is in line with the research of Leng and Ding (2014), stating that fraud committed by company management occurs due to a lack of information transparency that should be carried out through disclosure of internal control and the failure of companies in designing SPI. Weak internal control can lead to fraud (Fraud)

Disclosure of control over financial reports is a very important disclosure to reduce information asymmetry and improve corporate governance (GCG).

F. The effect of changes in public accountants on the quality of financial reporting.

The results of regression calculations on the changes in public accountants obtained a Wald value of 1.279 and a probability of 0.258 . Thus, the calculation of the probability is greater than the significant value of $0.05(0.258>$ 0.05), Ho is accepted, and $\mathrm{Ha}$ is rejected, meaning that the change in public accountants partially does not have a significant effect on the quality of financial reporting.

This study is in line with the research conducted by Widiyanti and Shanti (2014) and Rozania, et. el (2013) that they failed to find a relationship between the change in auditor and the quality of financial statements. There are other variables playing a role in strengthening or weakening the relationship between the change in auditor and the quality of financial reports. However, Aditiya and Wijayanti (2013) and Alshah (2015) provide evidence that the change in auditor has a positive effect on the quality of financial reports.

$\mathrm{G}$. The effect of the connection between $\mathrm{CEO}$ and the government on the quality of financial reporting.

Based on the results of the regression calculation on the connection between CEO and the government, the Wald value is 1.429 and the probability is 0.232 . Thus, the calculation of the probability is greater than the significant value of $0.05(0.232>0.05)$, Ho is accepted, and $\mathrm{Ha}$ is rejected, meaning that the connection between the CEO and the government partially does not have a significant effect on the quality of financial reporting.

This study is not in line with the research conducted by Chane et al (2010) and Nurhayati (2012) showing that companies with political relations tend to have poor reporting quality and care less about financial reports because they are protected from established political relations.

According to Sugiyarti (2017), political relations have a separate impact on the disclosure of financial information.

G.The effect of the GCG on the quality of financial reporting.

The results of the regression calculation on the of the GCG obtained a Wald value of 4,227 and a probability of 0.040 . Thus, the probability calculation is greater than the significance value of $0.05(0.040>0.05)$, Ho is rejected, and $\mathrm{Ha}$ is accepted, meaning that the the finding of fraud partially has a significant effect on the quality of financial reporting.

The quality of financial reporting is related to the overall performance of the company reflected in earnings (Fanani 2008). Financial information is said to be high (quality) if the current year's earnings can be a good indicator of future corporate profits. Lev and thiagarajan (1993). CEOs and commissioners have a duty to suppress earnings manipulation and in ensuring that they provide accurate accounting information about the company's operations

Young (1998) states that GCG describes a procedural procedure designed to improve the quality of financial reporting.

\section{CONCLUSIONS AND SUGGESTIONS}

\subsection{Conclusions}

1. Performance credibility, Go public company, The experience of director as an auditor, The age of CEO, Disclosure of material weaknesses, Change in public accountants, Connection between CEO and government, and Good Corporate Governance collectively have significant effect on the quality of financial reporting in BPD spread across Sumatra.

2. Disclosure of material weaknesses and Good Corporate Governance partially have significant effect on the quality of financial reporting in BPD spread across Sumatra.

3. Performance credibility, Go public company, The experience of director as an auditor, The age of CEO, Change in public accountants, Connection between CEO and government does not have significant effect on the quality of financial reporting in BPD spread across Sumatra.

4. The magnitude of the effect of the independent variables on the quality of financial reports is quite significant, namely $(65.5 \%)$, the remaining $34.5 \%$ is affected by other variables outside this study.

\subsection{Suggestions}

1. Further research is expected to increase the observation period to capture more information in an effort to maximize profit growth, besides that it is expected to be able to test samples not limited to banking companies only, and it is expected to use other proxies to measure research variables to obtain empirical evidence that strengthens analysis in achieving company goals.

2. Investors and creditors are expected to become a reference in making decisions related to financial reports. 
3. Company management is expected to be used as a reference to improve the quality of the Company's financial reports.

\section{REFERENCE}

Akins (2017) “Financial Reporting Quality and Uncertainty about Credit Risk among Rating Agencies" The Accounting Review, Volume 93, Page 1. October 2017.

Asare, Fitzgerald, Graham, Joe, Nagangard , and Wolfe (2013) “Auditors Internal control over Financial Reporting Decision : Analysis, Synthesis, and research Direction.” auditing A Journal of practice \& Theory, Volume 32, Page 131 . October 2012.

Bardhan, Lin, and Wu (2015) “ The Quality of Internal Control Over Financial reporting in Family Firms." Accounting Horizons, Volume 29, Page 41 . September 2014.

Bhandari , Mammadov, Shelton, and Thevenot (2018) "It not Only What you Know, It is also Who You Know : CEO Network Connection and Financial Reporting Quality" auditing A Journal of practice \& Theory, Volume 37, Page 27, May 2018

Bierstakerer, Chen, Christ, Ege, and Mintchik (2013) “ Obtaining Assurance for Financial Statement Audits and Control Audits When Aspect of the Financial Reporting Process Are Outsourced.." auditing A Journal of practice \& Theory, Volume 32, Page 131209. October 2012.

Bishop, Dezoort, and Hermanson (2017) "The Effect Of CEO Social Influence Presure and CFO Accounting Experience CFO Financial Reporting.”, Auditing A Journal of Practice \& Theory, Volume 36, Page 21 . Juni 2012.

Blondi, Glover, Jamal, Ohlson, Penman, Sunder,and Tsujiyama (2012) " Some of conceptual tension in Financial reporting."Accounting Horizons, Volume 26, Page 125 . March 2012.

merford, Hatfield, and Houston (2018) "The Affect of Earning Management on Auditor Scrutiny of Managements Other Financial Reporting Decisions.” The Accounting Review, Volume 93, Page 145 . March 2018.

Choudhary, Merkley, and Schipper (2019) "Auditors Quantitative Materiality Judgment": Properties and Implication for financial Reporting Reliability. Journal of Accounting Research Volume 36, Page 49 . July 2019

Diaz, Martin, and Thomas (2017) “ Financial Reporting Quality and Auditor Locality Contagion” auditing A Journal of practice \& Theory, Volume 36, Page 71. February 2017.

Easton (2016) "Financial Reporting :An Enterprise Operation Perspective." Journal of Financial Reporting, Volume 1, Page 143. September 2015.

Emma and Myllymaki,(2013) "The Persistence in the Association between section 404 material weaknesses and financial reporting Quality” auditing A Journal of practice \& Theory, Volume 33, Page 93 . October 2013.

Fanani, Zainal, 2008.Kualitas pelaporan keuangan. Factor factor penentu konsekkwensi ekonomi, 2 nd Accounting Conference, $1^{\text {st }}$ doctoral Coloquium and accounting Workshop.

Gaynor, Kelton, Mercer, and Yohn, (2016) " understanding the relation between Financial Reporting Quality and Audit Quality" auditing A Journal of practice \& Theory, Volume 35, Page 1. March 2016.

Garven, Beck and Parsons (2018) " are audit Related factors associated with Financial Reporting Quality" auditing A Journal of practice \& Theory, Volume 37, Page 49 . June 2017.

Goode, Newton, and Thomson (2017) " Business Strategy, Internal Control over Financial Reporting and Audit Reporting Quality" auditing A Journal of practice \& Theory, Volume 36, Page 49 . February 2017.

Ham, Lang, Seybert and Wang (2017). " CFO Narcissism and Financial Reporting Quality" Journal Accounting Research, Volume 55, Issu 5, April 2017.

Huang, Green, and Lee,(2012) “CEO Age Financial Reporting Quality” The Accounting Horizons, Volume 26, Page 725 . July 2012.

Hutauruk, Martinus Robert (2017).Akuntansi Perusahaan Jasa Aplikasi Program Zahir Accounting Versi 6.Jakarta Barat : Indek

Hops, Thomas, and Vyas. (2013)., Financial Reporting Quality of U.S.Pivate and Public Firms “. Accounting Review, Vol. 88 page 1715. April 2013.

Krishnan, Wen and Zhao (2011 )." Legal Expertise on Corporate Audit Comitte and financial reporting Quality". The Accounting Reeviw, Volume 86, Page 2099. Yuly 2011.

Liang, Marinovic and Varas, (2018)., The Credibility of Financial Reporting : A Reputation Based Approuch. The Accounting review, Volume 93, Page 317, Issue 1. 2017.

Litt , Simsons, and Tanyl (2014) “Audit Partner Rotation and Financial Reporting Quality” auditing A Journal of practice \& Theory, Volume 33, Page 59 . March 2014.

Mardiasmo.(2018). Akuntansi sektor publik. Penerbit Andi, Yogyakarta.

Nagar and Petacch (2016)., “A Model Of Aggregate reporting Quality”.. Jurnal of financial Reporting, Vol. 1. ( 2016) pp. 1-19.

Ole-Kristian Hope (2013) “ Financial Reporting Quality of U.S Private and Public Firms “ The Accounting 
Review, Volume 88, Page 1715-1742, April 2014. 